\title{
10. Különleges jogrend különleges intézkedésekkel Dániában
}

NÉMETH ZOLTÁN

\section{A különleges jogrend alkotmányos és törvényi szintư szabályozása, valamint a különleges jogrend és esetkörei}

Dániában alkotmányos szinten a különleges jogrend területe lényegében szabályozatlan. ${ }^{1}$ A rendkívüli állapotra vonatkozóan az alkotmány 23. cikke² a következőt rögzíti: „Rendkívüli állapot esetén, amennyiben a parlament nem ülhet össze, a király ideiglenes jogszabályokat hozhat, amennyiben azok nem ellentétesek az alkotmánnyal; ezeket a parlament összehívásakor azonnal be kell terjeszteni megerősítésre vagy elutasításra."

Számos európai alkotmánnyal ellentétben ${ }^{3}$ tehát a dán alkotmány igen szúkszavú a különleges jogrenddel kapcsolatban - nincs általános alkotmányos rendelkezése a rendkívüli állapotnak, és csak egy külön cikk szól a szükségállapotról.

A dán hatóságok a koronavírus-járvány első hullámában azonnal reagáltak, és az alapvető jogokat korlátozták, különösen a gyülekezési szabadságot, valamint az alkotmányos polgári

1 Ságvári, 2016, 2. o.

2 Nemzeti Alkotmányok az Európai Unióban, 2016, 233. o.

3 Fallentin Nyborg et al., 2020, 1. o.

Dr. Németh Zoltán, LLM

zoltan.nemeth@mfi.gov.hu

kutató (Mádl Ferenc Összehasonlító Jogi Intézet)

Németh, Z. (2021) 'Különleges jogrend különleges intézkedésekkel Dániában' in Nagy, Z., Horváth, A. (szerk.) A különleges jogrend és nemzeti szabályozási modelljei, 241-251. o. Budapest: Mádl Ferenc Összehasonlító Jogi Intézet.

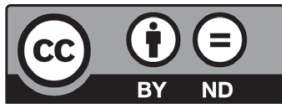


és politikai jogokat. Az alkotmányos szabályoknak kellően rugalmasnak kell lenniük, hogy ilyen rendkívüli helyzetekre is tudjanak reagálni, de Dánia történetében még csak hasonló sem fordult elő eddig, ezért a jogalkotó erre eddig nem tudott felkészülni. ${ }^{4}$

\section{Az alapjogok korlátozásával kapcsolatos kérdések}

A dán alkotmány részletesen foglalkozik az alapjogok kérdéskörével, és meghatározza azok körét a nyolcadik fejezetében. Az alkotmány azt a szabályozási rendszert követi, hogy alapvetően az általa felsorolt alapjogok korlátozását nem engedélyezi, kivéve, ha azokat külön törvényben vagy a köz érdekében korlátozni szükséges. Az alábbi táblázat összefoglalja az alkotmány alapjogi rendszerét és az alapjogok korlátozási lehetőségeit. ${ }^{5}$

\begin{tabular}{|c|c|c|c|}
\hline Alapjog & $\begin{array}{l}\text { Helye az alkot- } \\
\text { mányban }\end{array}$ & Az alapjog terjedelme & A korlátozás lehetősége \\
\hline Személyi szabadság & 71. cikk & Sérthetetlen & Törvény alapján \\
\hline Lakás & 72. cikk & Sérthetetlen & $\begin{array}{l}\text { Bírói rendelkezésre vagy } \\
\text { különleges törvényi } \\
\text { rendelkezés alapján }\end{array}$ \\
\hline Tulajdonjog & 73. cikk & Sérthetetlen & $\begin{array}{l}\text { Törvényben és teljes } \\
\text { kártalanítás mellett }\end{array}$ \\
\hline $\begin{array}{l}\text { Kereskedelemhez } \\
\text { való jog }\end{array}$ & 74. cikk & $\begin{array}{l}\text { Egyenlő és szabad } \\
\text { hozzáférhetőség }\end{array}$ & Kizárólag közérdeken alapulhat \\
\hline Munkához való jog & 75. cikk & Létfenntartás & Törvény szabályozza \\
\hline $\begin{array}{l}\text { Ingyenes általános } \\
\text { iskolai oktatás }\end{array}$ & 76. cikk & $\begin{array}{l}\text { Az iskoláskorú gyer- } \\
\text { mekek jogosultak rá }\end{array}$ & Törvény szabályozza \\
\hline $\begin{array}{l}\text { Szabad } \\
\text { véleménynyilvánítás }\end{array}$ & 77. cikk & $\begin{array}{l}\text { Korlátlan, de bírósági } \\
\text { felelősségvállalás mellett }\end{array}$ & Nem korlátozza törvény \\
\hline Egyesülési szabadság & 78. cikk & Előzetes engedély nélkül & Törvény szabályozza \\
\hline $\begin{array}{l}\text { Gyülekezési } \\
\text { szabadság }\end{array}$ & 79. cikk & Előzetes engedély nélkül & $\begin{array}{c}\text { Korlátozható, ha veszélyt jelent } \\
\text { a közrendre }\end{array}$ \\
\hline
\end{tabular}

6. táblázat

A dán alkotmány alapjogi rendszere

Forrás: a szerző saját összeállitása

4 Klinge et al., 2020, 131. o.

5 Nemzeti Alkotmányok az Európai Unióban, 2016, 239. o. 


\section{Egészségügyi vészhelyzet kezelése, koronavírus-járvány}

\section{1. A koronavírus-járvány első hulláma Dániában}

A parlament - amely a járványhelyzetben is folyamatosan ülésezett ${ }^{6}$ - a koronavírus-járvány első hullámának indulásakor, 2020 márciusában egyhangúlag elfogadta a dán járványügyi törvény ${ }^{7}$ módosítását, ${ }^{8}$ amely felhatalmazza az egészségügyi hatóságokat arra, hogy a rendőrség támogatásával vizsgálatokat folytassanak és intézkedéseket tegyenek. De jure értelemben Dánia nem vezetett be különleges jogrendet. ${ }^{9}$

A törvény képezi a Covid-19-járvány elleni küzdelem során szükséges legátfogóbb korlátozások alapját. ${ }^{10} \mathrm{~A}$ törvény több módosításában a parlament felhatalmazta a kormányt, hogy számos korlátozást, tilalmat vezessen be. Ez vonatkozik például az egyesületi, alapítványi közgyúlések tilalmára, az üzletek, éttermek bezárására, valamint a tömegközlekedés használatának korlátozására. Ezenkívül a kormány utasítást adhat ki magánszemélyeknek, és külön korlátozásokat szabhat a vállalkozásokra, például a közlekedési társaságokra az áruk és az orvosi felszerelések ellátásának biztosítása érdekében. A törvény számos alkotmányos jogot érint, beleértve a gyülekezés szabadságát és a tulajdonjogot.

A hatóságok által a Covid-19-cel kapcsolatban bevezetett intézkedések potenciális hatással vannak az alkotmányosan biztosított jogokra, például a személyi szabadság sérthetetlenségére, ${ }^{11}$ a gyülekezési szabadságra, ${ }^{12}$ valamint az Emberi Jogok Európai Egyezménye által biztosított jogokra, például a családi és magánélethez való jogra, a gyülekezési szabadságra, valamint a tulajdonhoz való jogra. ${ }^{13}$

A Covid-19-re vonatkozó szabályokat a Járványtv. módosításával vezették be. ${ }^{14} \mathrm{~A}$ törvény egyértelmúen olyan kerettörvény, amely a kormánynak, nevezetesen az egészségügyi miniszternek lehetőséget biztosít külön szabályok bevezetésére végrehajtási utasítások kiadásával. Ezek a szabályok később azonnal hatályba léphetnek. Nagyon fontos, hogy ezek a szabályok elsőbbséget élveznek minden más nemzeti jogszabály előtt (az alkotmány kivételével).

A korlátozásoknak azonban ideigleneseknek és arányosaknak kell lenniük, és meghatározott értékelések alapján meghatározott területekre korlátozódhatnak. A kormány több végrehajtási rendeletet adott ki, amelyek ilyen korlátozásokat írtak elő - ilyen volt többek

6 Venice Commission, 2020, 18. o.

7 Lov om foranstaltninger mod smitsomme og andre overførbare sygdomme (a továbbiakban: Járványtv.)

8 2020. 03. 17-i 208. számú törvény a fertőző betegségek és más fertőző betegségek elleni intézkedésekről szóló törvény módosításáról (Lov nr. 208 af 17-03-2020 lov om ændring aflov om foranstaltninger mod smitsomme og andre overførbare sygdomme).

9 Venice Commission, 2020, 14. 0.

10 Dittmer-Edelgaard, 2020.

11 Alkotmány 71. cikk.

12 Alkotmány 79. cikk.

13 European Union Agency for Fundamental Rights, 2020.

14 Járványtv. 27. \$. 
között a nagyobb gyülekezések tilalmáról, valamint az egyes létesítményekhez való hozzáférés tilalmáról és korlátozásáról szóló végrehajtási rendelet ${ }^{15}$ vagy a közlekedési ágazatban hozott intézkedésekről szóló végrehajtási rendelet. ${ }^{16} \mathrm{~A}$ végrehajtási rendelkezések 2020. március 18 -án 10 órakor léptek hatályba. E végrehajtási szabályozások legfontosabb rendelkezéseit az alábbiakban ismertetjük.

A Járványtv. további hatásköröket adhat a kormánynak, ideértve a 10 főnél kisebb létszámú gyưlések tilalmát is, amennyiben az egészségügyi hatóságok ajánlása alapján történik. 2020. április közepétől a kormány több intézkedést jelentett be Dánia fokozatos újranyitására számos korlátozás enyhítésével, amennyiben ezt az egészség szempontjából biztonságosnak tartják. A korlátozások fő része, például a gyülekezési tilalom tiltása eredetileg 2020. május 11-ig volt érvényben, azonban várhatóan az intézkedések nagy része hosszú ideig még érvényben marad. A nagygyúlések tilalma már 2020. szeptember 1-jéig volt érvényes.

A törvényt számos más törvény és szabály egészíti ki. Ez vonatkozik többek között a beutazási korlátozásokra és a határok lezárására, amelyeket a schengeni megállapodás alapján kezdetben 2020. április 13-ig kezdeményeztek. A kormány elkészített egy útmutatót a Covid19-járvány által érintett vállalkozások számára, ${ }^{17}$ valamint egy weboldalt a Covid-19-rôl dán nyelven. ${ }^{18}$

Az üzleti és ipari szempontból a legfontosabb rendelkezések között meg kell említeni, hogy a kormány megtilthatja vagy korlátozhatja azoknak a létesítményeknek a hozzáférését, amelyekkel az üzleti vállalkozások tulajdonosai rendelkeznek, és amelyekhez általános a nyilvánosság hozzáférése. A kormány szerint ezek lehetnek kompkikötők, repülöterek, állomások és találkozóhelyek, például fitneszközpontok, éttermek, koncerttermek, szoláriumok stb. A jogi keretben azonban nincsenek külön korlátozások, ezért a kormány elő́rhat bármilyen létesítménytípusra vonatkozó korlátozásokat.

A gyülekezési jog tilalmáról szóló végrehajtási rendelet ${ }^{19}$ 6. szakasza szerint a következő létesítményeket le kell zárni a nyilvánosság előtt:

15 2020. 04. 17-i 442. számú végrehajtási rendelet a nagygyúlések tilalmáról, valamint az egyes létesítményekhez való hozzáférés tilalmáról és korlátozásáról (Bekendtgørelse om ændring af bekendtgørelse om forbud mod større forsamlinger og mod adgang til og restriktioner for lokaler i forbindelse med håndtering af Covid-19 - BEK nr 442 af 17/04/2020).

16 2020. 03. 17-i 22. számú végrehajtási rendelet a közlekedési ágazatban hozott intézkedésekről (Bekendtgørelse om foranstaltninger mod smitsomme og andre overførbare sygdomme på transportområdet - BEK nr 220 af 17/03/2020).

17 Elérhető: www.virksomhedsguiden.dk (Letöltve: 2020 . december 10.).

18 Elérhető: www.politi.dk/coronavirus-i-danmark (Letöltve: 2020. december 10.).

19 2020. évi 1971-es végrehajtási rendelet a nagygyưlések tilalmáról, valamint a helyiségekhez való hozzáférésről, illetve a COVID-19 kezelésével kapcsolatos korlátozásokról szóló végrehajtási rendelet módosításáról (BEK nr 1971 Bekendtgørelse om ændring af bekendtgørelse om forbud mod større forsamlinger og mod adgang til og restriktioner for lokaler og lokaliteter i forbindelse med håndtering af Covid-19) (A továbbiakban: Gyülekezési tilalom r.). 
- helyeket, ahol ételeket és italokat szolgálnak fel, vagy ahol az értékesítési helyen fogyasztandó dohányt értékesítik; élelmiszerek és italok elvitelként történő értékesítése azonban megengedett;

- bevásárlóközpontokat, játéktermeket és bazárokat, valamint az ezekben található üzleteket, kivéve, ha az üzletek közvetlenül az utcáról érhetők el, és az orvosi eszközöket árusító kisboltokat, gyógyszertárakat és szaküzleteket;

- helyeket, ahol sport- és szabadidős tevékenységeket gyakorolnak, beleértve a szerencsejáték-termeket, játszótereket és vízi parkokat, nyilvános uszodákat, fitneszközpontokat, színházakat és mozikat; a szükséges rehabilitációhoz használt létesítmények kivételével;

- tetováló- és piercingszalonokat, gyógyfürdőket, testápolási és szépségápolási klinikákat, masszázsklinikákat, fodrászatokat és más létesítményeket, amelyek olyan szolgáltatásokat kínálnak, amelyek szoros fizikai kapcsolatot jelentenek az ügyfelekkel, valamint a szoláriumokat.

A tilalom 2020. április 20-ig volt hatályban a személyes fizikai kontaktusban dolgozó kisvállalkozások, például a fodrászok, a szépségklinikák és a masszázsklinikák stb. számára. Ezeket az első hullám végén újra lehetett nyitni.

A kormány a Járványtv. alapján a fent említett tilalmak helyett a maximális kihasználtságra és más hasonló korlátozásokra vonatkozó szabályokat írhat elő, például a befogadóképességhez képest csak bizonyos számú ember tartózkodását engedélyezheti, vagy olyan követelményeket támaszthatnak, amelyek szerint az üzleti helyiségekben az embereknek bizonyos távolságot kell tartaniuk. Ezt például szupermarketekben, gyógyszertárakban és más kritikus vállalkozásokban lehet eloórni, ahol a tilalom nem kívánatos, de más korlátozásokra szükség van.

A Gyülekezési tilalom r. 7. szakaszában a kormány számos korlátozást vezetett be minden nyilvános hozzáféréssel rendelkező létesítménytulajdonosra. Ezek a korlátozások tehát nem csak bizonyos típusú létesítményekre vonatkoznak. A vállalkozás tulajdonosának meg kell győződnie arról, hogy ezek a követelmények teljesülnek:

- 4 négyzetméter alapterületen legfeljebb 1 fő engedélyezhető (az alapterületet faltól falig kell mérni, függetlenül a bútoroktól és a felszereléstől stb.);

- a létesítményeket a lehető legnagyobb mértékben úgy kell megszervezni, hogy minimalizálják a fertőzés kockázatát, többek között lehetővé téve az ügyfelek és a látogatók számára, hogy távolságot tartsanak egymás között;

- a létesítményekben vagy azok közelében tájékoztató anyagokat kell elhelyezni annak érdekében, hogy a Covid-19 tüneteivel küzdő emberek otthon maradjanak elszigetelten (az információs anyagnak meg kell felelnie a dán egészségügyi hatóság utasításainak); 
- biztosítani kell, hogy minden alkalmazott betartsa az egészségügyi hatóság jó higiéniára és megfelelő viselkedésre vonatkozó ajánlásait;

— a lehetőségekhez mérten kézfertôtlenítőt kell a látogatók részére biztosítani;

- a nem csomagolt élelmiszerek értékesítésekor az alkalmazottaknak kesztyút kell használniuk.

Ha a vállalkozások nem tartják be a fent említett korlátozásokat, a rendőrség elrendelheti a létesítmény bezárását egy meghatározott időszakra. ${ }^{20}$

A kormány el akarta kerülni azokat a nagy összejöveteleket, amelyek a betegség terjedésének nagy kockázatával járnak. A Járványtv. rendelkezései értelmében a kormány megkapja annak lehetőségét, hogy megtiltsa a nagygyưlések, egyeztetések, rendezvények stb. szervezését és az azokon történő részvételt. Ez magában foglalhatja beltéri, kültéri és nyilvános, valamint magángyưléseket (kivéve a magánlakásokban zajló eseményeket). A tiltások bármilyen típusú eseményre kiterjedhetnek, például koncertekre, sporteseményekre, partikra, közgyúlésekre és társaságokban vagy egyesületekben tartott találkozókra.

Először is, a kormány a Gyülekezési tilalom r. 1. szakaszában tiltást vezetett be, amely elözetesen 2020. május 11-ig volt hatályban. Másodszor, a kormány 2020. szeptember 1-ig megtiltotta a több mint 500 résztvevőből álló nagygyúléseket. A tilalom azt jelenti, hogy fesztiválok, koncertek, sportesemények stb. ebben az időszakban nagyrészt nem lesznek engedélyezettek.

E törvény értelmében a kormány felhatalmazást kapott arra, hogy általában megtiltsa a kevesebb mint 10 résztvevős gyülekezéseket is. Ehhez azonban meg kell követelni, hogy ez az egészségügyi hatóságok ajánlásain alapuljon, és csak akkor, ha a kevésbé radikális intézkedéseket nem tartják elégségesnek. A törvényjavaslat memoranduma feltételezi, hogy a tilalom nem vonatkozik az ugyanazon lakóhelyen lévő vagy közeli hozzátartozóikra. Ilyen tilalmat nem vezettek be, és várhatóan nem is alkalmazzák a későbbiekben sem.

A kormány megkapta annak lehetőségét, hogy bezárja azokat a meghatározott területeket, amelyekről úgy tartják, hogy különleges fertőzésveszélyt hordoznak. Ezenkívül a rendőrség lehetőséget kapott arra, hogy teljes mértékben megtiltsa bizonyos helyek látogatását, ahová a betegség terjedésének veszélye miatt a nyilvánosság általában hozzáfér. Ez vonatkozik például terekre, parkokra, utakra, strandokra, vidámparkokra, vasútállomásokra, repülőterekre, üzletekre és bevásárlóközpontokra. A tilalom látogatási tilalom volt, és nem kijárási korlátozás. ${ }^{21}$

A törvény értelmében a kormány utasíthat bárkit, aki fertőzött a Covid-19-cel, vagy bárkit, aki vélelmezhetően fertőzöttnek tekinthető, hogy vizsgáltassa meg magát, és vonuljon önkéntes karanténba. A hatóságok azonban a magánszemélyek lakóhelyeire nem mehettek be olyan bírósági végzés nélkül, amely figyelembe veszi az otthon sérthetetlenségének alkot-

20 Gyülekezési tilalom r. 8. cikk.

21 A korlátozás egy konkrét létesítményre vonatkozott, és nem általánosan mindenre egy meghatározott idősávon belül. 
mányos védelmét, vagyis az alkotmány 72 . szakaszát. ${ }^{22} \mathrm{~A}$ kormány megtilthatta a fertőzött személyeknek a tömegközlekedés használatát. Ez vonatkozik azokra a személyekre is, akik fertőzöttek lehetnek (például a nyilvánvaló tünetek alapján). Ez azt is jelenti, hogy kényszer alkalmazható azon utasokkal szemben, akik nem múködnek együtt.

A dán egészségügyi miniszter megtilthatta a közlekedési eszközökhöz való hozzáférést, és korlátozásokat állapított meg a maximális kihasználtságra vonatkozóan. Ez lehet például az a tilalom, hogy a szokásos befogadóképesség egynegyedénél több utast vegyenek fel, vagy ne legyen több utas, mint ahány férőhely van. A szabályok vonatokra, buszokra, villamosokra, metrókra, repülőgépekre és kompokra alkalmazhatók. A szabályok az állami és a magánszektorra egyaránt vonatkoztak. A kormány korlátozásokat vezetett be a távolsági buszok kihasználtságára, hogy azok maximálisan az utasok 50\%-ának megfelelő utast szállíthassanak. ${ }^{23}$

Az egészségügyi hatóságok 2020. április 4-i hatállyal előírhatják a vállalkozások számára, hogy egészségügyi információkat nyújtsanak be a betegség terjedésének megakadályozása érdekében. Fontos, hogy az információnak relevánsnak kell lennie.

A kormány egyedi szabályokat alkotott az áruellátás biztosítására. Ez magában foglalhatja a magánkereskedők által értékesített fontos javak kisajátítását. Kisajátítás esetén teljes kártérítést kell fizetni az alkotmány 73. szakasza alapján. ${ }^{24} \mathrm{~A}$ kormány külön végrehajtási rendeleteket adott ki az orvosi berendezésekról, ideértve a fertőtlenítőszer-ellátással kapcsolatos különleges intézkedéseket ${ }^{25}$ és a gyógyszer forgalmazásának korlátozását ${ }^{26}$ (a 2020. április 8-i 399. számú végrehajtási rendelet).

A közlekedési miniszter (a Járványtv.-tôl függetlenül) bizonyos sürgôsségi intézkedéseket hozott a szárazföldi szállítással történő áruellátás biztosítása érdekében, ideértve a képzési követelmények enyhítését és a pihenőidő szabályait. Ezen követelmények némelyikét a jármûvezetők kölcsönzésére vonatkozó tilalom ideiglenes hatályvesztéséről szóló végrehajtási rendelet határozza meg. ${ }^{27}$

22 Nemzeti Alkotmányok az Európai Unióban, 2016, 239. o.

23 2020. április 20-i 457. számú végrehajtási rendelet a távolsági buszok maximális megengedett kihasználtságáról (BEK nr 457 af 20/04/2020 Bekendtgørelse om maksimal tilladt belægning i fjernbusser som led i håndtering af Coronavirussygdom 2019 [COVID-19]).

24 Nemzeti Alkotmányok az Európai Unióban, 2016, 239. o.

25 2020. 03. 25-i 277. számú végrehajtási rendelet az árucikkek szállítására vonatkozó különleges intézkedésekről (BEK nr 277 af 25/03/2020 Bekendtgørelse om særlige foranstaltninger vedrørende forsyning af desinfektionsmidler i forbindelse med håndtering af Coronavirussygdom 2019 [COVID19]).

26 2020. 04. 08-i 399. számú végrehajtási rendelet a gyógyszer forgalmazásának korlátozásairól (BEK nr 399 af 08/04/2020 Bekendtgørelse om ændring af bekendtgørelse om lægemiddelberedskabet i forbindelse med håndtering af Coronavirussygdom 2019 [COVID-19]).

27 2020. 03. 27-i 304. számú végrehajtási rendelet a sürgősségi intézkedésekről a szárazföldi szállítással történő áruellátás biztosítása érdekében, ideértve a képzési követelmények enyhítését és a pihenőidő szabályait (BEK nr 304 af 27/03/2020 Bekendtgørelse om ændring af bekendtgørelse om midlertidig ophævelse af forbud mod chaufførudlån og særlig forlængelse af kørekort, chaufføruddannelsesbevis, uddannelsesbevis og sikkerhedsrådgiverbevis til sikring af forsyningen af varer i forbindelse med håndtering af Coronavirussygdom 2019 [COVID-19]). 
A kormány hazánkhoz hasonlóan meghosszabbította a közgyúlések (például egyesületek esetén) tartásának és az éves jelentések benyújtásának határidejét. A kormány azonban meghatározta, hogy ez nem vonatkozik azokra a kötelezettségekre, amelyek magánszektorbeli szereplőknek a hatóságok vagy más magánszereplők irányába tett megállapodásain alapulnak. A megállapodásoktól függ, hogy a járvány miatt a felek milyen mértékben mentesülhetnek a megállapodások teljesítése alól.

A kormány az első hullám során bejelentette, hogy az egészségügyi miniszter feladata annak értékelése, hogy felhatalmazást kap-e a szükséges speciális szabályok kiadására. A kérdést végül bírósági felülvizsgálatnak vetik alá, így a vállalkozásoknak van lehetőségük panasszal élni minden felesleges vagy aránytalan intézkedéssel kapcsolatban. A kormány azonban azon az állásponton volt, hogy a vállalkozásoknak be kell tartaniuk a kormány utasításait, így a kormány felelôs a ténylegesen szükséges lépésekért.

A rendőrség és a hatóságok kiterjesztett hozzáférést kapnak a kényszerintézkedések bírósági végzés nélküli meghozatalához a törvény betartásának biztosítása érdekében. A kormány azonban visszavonta a kényszerintézkedések bírósági végzés nélküli végrehajtásának lehetőségét, figyelembe véve az alkotmánynak az otthon sérthetetlenségéről szóló 72. szakaszát.

A szabályok megsértése pénzbüntetéssel vagy súlyosabb esetben legfeljebb hat hónapos börtönnel büntethetô. Ami a vállalkozásokra kiszabott bírságokat illeti, figyelembe kell venni a vállalkozásban a búncselekmény idején alkalmazottak számát.

A kormány a törvényjavaslat memorandumában rögzítette az eredetileg rögzített bírságoknál magasabb ajánlott bírságszinteket. Az új szintek:

- a nagygyúlések tilalmának megsértése: 2500 DKK bírság első búncselekmény esetén; ${ }^{28}$

- a vállalkozások mulasztása esetén 10000 DKK bírság kisvállalkozásoknak (legfeljebb kilenc alkalmazott), 20000 DKK közepes méretú vállalkozásoknak (10-49 alkalmazott) és 40000 DKK nagyvállalkozásoknak (50 vagy annál több alkalmazott); a bírság 100\%-kal, illetve 150\%-kal emelhetô a második, illetve a harmadik búncselekmény esetén;

- ha a vállalkozások nem tartják be a bizonyos helyiségekre vonatkozó korlátozásokat, akkor alapesetben 3000 DKK bírság szabható ki.

A többi végrehajtási rendelet megsértése pénzbüntetéssel és legfeljebb hat hónapos börtönbüntetéssel büntethetô.

28 Gyülekezési tilalom r. 1. cikk. 


\subsection{A második hullám intézkedései}

2020. október 23-án a dán kormány úgy határozott, hogy új korlátozásokat vezet be, amelyek 2020. október 26. és 2021. január 2. között lesznek hatályosak. Az új korlátozások magukban foglalják azt a követelményt, hogy 2020. október 29-tôl a kiskereskedelmi üzletekben és bizonyos mértékig az oktatási intézményekben kötelező a maszk viselése. Korlátozásokat vezettek be az alkohol árusításában a szupermarketekben és a kioszkokban 22:00 óra után, és mindenkit arra biztattak, hogy korlátozza a társas kapcsolatok számát. Ezenkívül fokozták a határellenőrzést. Az összejövetelek létszámát 10 főben maximálták, kivéve a temetéseket, amelyeken 50 fő vehetett részt. Ezek a korlátozások 2020. december 13-ig érvényesek. ${ }^{29}$

A jelenleg, a koronavírus második hullámában hatályban lévő intézkedések:

- az összejövetelek résztvevőit 10 főben maximálták (hatályos 2020. október 26-tól 2020. december 13-ig);

- arcmaszk viselésének követelménye a kiskereskedelmi üzletekben és kioszkokban (hatályos 2020. október 29-tôl 2021. január 2-ig);

- arcmaszk viselésének követelménye - bizonyos mértékig - az oktatási intézményekben (hatályos 2020. október 29-tôl 2021. január 2-ig);

- az alkohol árusításának korlátozása a kiskereskedelmi üzletekben és kioszkokban 22:00 óra után (hatályos 2020. október 26-tól 2021. január 2-ig);

- bátorítás a társas kapcsolatok számának korlátozására (hatályos 2020. október 26-tól 2020. december 13-ig).

Fontos megemlíteni, hogy az egészségügyi hatóságok komoly erőfeszítéseket tesznek az ország lakosságának felvilágosításában, információval történő ellátásában, mivel ez lehet az egyik legjobb eszköz a járvány terjedésének érdemi lassítására, az úgynevezett járványgörbe ellaposítására. Ennek érdekében több tematikus honlap is múködik, amelyek információkkal látják el a lakosságot. Ezeken írásbeli anyagok, videók is megtalálhatók, amelyek például a maszkviselés helyes szabályaira is felhívják a figyelmet. ${ }^{30} \mathrm{~A}$ koronavírus-járvánnyal foglalkozó legjelentősebb az angol nyelven is elérhető honlap, ${ }^{31}$ amelyen minden aktuális információ megtalálható tematizált formában, így is közérthetőbbé téve a háttérjogszabályokat. ${ }^{32}$

29 Hivatalos tájékoztató honlap a koronavírusról: https://coronasmitte.dk/en/overview (Letöltve: 2020. november 26.).

30 Danish Healt Authority honlapja: www.sst.dk/en/English/publications (Letöltve: 2020. november 26.).

31 Elérhető: https://coronasmitte.dk/en (Letöltve: 2020 . november 26.).

32 A koronavírus hivatalos kormányzati honlapja: https://coronasmitte.dk/en (Letöltve: 2020 . november 26.). 


\section{Különleges jogrend, járványügyi vészhelyzet kihirdetésével kapcsolatos tapasztalatok, jogviták}

A koronavírus-járvány során Dániában a vállalkozások tevékenységének korlátozása és az alkotmányban szabályozott kisajátítás kérdésköre körül alakult ki jogértelmezési dilemma. A kormány az első hullám során bejelentette, hogy az egészségügyi miniszter feladata annak értékelése, hogy felhatalmazást kap-e a szükséges speciális szabályok kiadására. A kérdést végül bírósági felülvizsgálatnak vetették alá, így a vállalkozásoknak van lehetőségük panasszal élni minden felesleges vagy aránytalan intézkedéssel kapcsolatban. A kormány azonban azon az állásponton volt, hogy a vállalkozásoknak be kell tartaniuk a kormány utasításait, így a kormány felelős a ténylegesen szükséges lépésekért.

A módosított törvény a Járványtv. - a vállalkozásoknak kompenzációt nyújtó - 27. szakaszát hatályon kívül helyezi. A kormány ezt azzal indokolta, hogy nem hiszi, hogy képesek lennének felmérni a korábbi rendelkezések gazdasági hatásait, ha aktiválnák őket. Ehelyett a kormány bejelentette, hogy az üzleti vállalkozásokkal és az iparral együttmúködve speciális kompenzációs rendszereket és egyéb mentőcsomagokat készít az intézkedések következményeinek „észszerú kompenzációja” biztosítása érdekében.

A kormány számos rendszert vezetett be a kereskedelem és az ipar támogatására: bérek és fizetések kompenzációs rendszere, a vállalkozások állandó költségeinek fedezésére szolgáló kompenzációs rendszer és a Dán Ipari Növekedési Alap keretében megvalósuló speciális garanciarendszerek formájában.

A kormány mentőcsomagjai nagyrészt kizárólag a költségeket fedezik, és nem az elveszett bevételeket. Ezért fontos, hogy a vállalkozások jogosultak legyenek „teljes kártérítésre”, ha az intézkedések az alkotmány 73. szakasza alapján kisajátításnak minősülnek. Eleinte ez az elveszített nettó nyereség megtérítésének igényét jelentheti. A legtöbb vállalkozás tekintetében azonban ez nem így lesz, ha az intézkedéseket általánosnak és nem konkrétnak tekintik, ami mellett szól, hogy ez kompenzációmentes szabályozás. Az intézkedések azonban annyira radikálisak lehetnek, hogy egyes vállalkozások esetében kisajátításnak tekinthetők, ami a tényleges átadás egyik formája. A kormány jelezte, hogy ez a helyzet állhat fenn, ha tilalmat írnak elô a lakosság vállalkozásai tulajdonához való hozzáférésére.

\section{5. Összegzés}

A dán szabályozás a különleges jogrenddel és az alapjogi korlátozásokkal összefüggésben a magyarhoz képest kevésbé részletes. Különösen a különleges jogrendi szabályokat érdemes megemlíteni, amelyről az alkotmány mindössze egy bekezdése rendelkezik. A dán történelmi hagyományok miatt a jogalkotók nem gondolkodtak ennél részletesebb szabályozáson, ezért a koronavírus-járvány kitörésekor szembesültek azzal, hogy a szabályozat- 
lanság miatt nagyon merev az alkotmány, ami nehezítheti a hatékony és gyors fellépést ilyen súlyos járványhelyzetben. A koronavírus egyes hullámainak kezelése szempontjából megállapítható, hogy a kormány időben előbb hozott intézkedéseket, de ott előbb is jelentkeztek a járványhelyzet negatív hatásai. Annyiban a dánok jó megoldást választottak, hogy az első hullámban hozott intézkedések hatályát egészen 2021 márciusáig kitolták, így nem volt szükség jogalkotói beavatkozásra a második hullámig, amikor viszont további, a magyar intézkedésekhez nagyon hasonló korlátozásokat vezettek be. A lakosság tájékoztatása szempontjából is mutatkozik hasonlóság a két ország között, mivel hazánkban és Dániában is informatív, áttekinthető tájékoztató honlap áll az érdeklődők rendelkezésére.

A két ország nehezen összehasonlítható, ha az alkotmányaikban található szabályokat vizsgáljuk, de az bizonyos, hogy a dán jogalkotó érzékenyebb az alapjogok korlátozása terén, és sokkal nehezebben hoz korlátozó intézkedéseket, ami a dán hagyományokra is visszavezethető.

\section{Irodalomjegyzék}

SÁGVÁRI, Á. (2016) Különleges jogrenddel a terror ellen - kitekintés az európai gyakorlatra [Online]. Elérhetô: https://jog.tk.mta.hu/blog/2016/o2/kulonleges-jogrenddel-a-terror-ellen (Letöltve: 2020. november 26.)

Nemzeti Alkotmányok az Európai Unióban (2016). Budapest: Wolters Kluwer

FAllentin NyborG, A., Klinge, S., KRUnKe, H., RytTER, J. E. (2020) ‘Covid-19 and Emergency Laws in Denmark', Svensk Juristtidning, 10(20), 1098-1115. o.

Klinge, S., Krunke, H., FAllentin Nyborg, A., Rytter, J. E. (2020) 'Covid and Constitutional Law in Denmark' in Serna de la Garza, J. M. (szerk.) Covid-19 and Constitutional Law. Covid-19 et droit constitutionnel. 1. kiadás. México: Universidad Nacional Autónoma de México

Dittmer, M., Edelgaard, T. (2020) The Danish Epidemic Act [Online]. Elérhető: https:// gorrissenfederspiel.com/en/knowledge/news/Covid-19-the-danish-epidemic-act (Letöltve: 2020. november 26.)

European Union Agency for Fundamental Rights (2020) Coronavirus COVID-19 Outbreak in the EU. Fundamental Rights Implications [Online]. Elérhetô: https://fra.europa.eu/sites/default/files/ fra_uploads/denmark-report-Covid-19-april-2020_en.pdf (Letöltve: 2020. november 26.)

Venice Commission (2020) Interim Report on the Measures Taken in the EU Member States as a Result of the COVID-19 Crisis and Their Impact on Democracy, the Rule of Law and Fundamental Rights (Study No. 995/2020) [Online]. Elérhető: https://www.venice.coe.int/webforms/ documents/?pdf=CDL-AD(2020)018-e (Letöltve: 2020 . december 15.) 